\title{
TRADISI INTEGRASI ILMU DALAM INSTITUSI PENDIDIKAN ISLAM
}

\section{Zainal Abidin*}

Sekolah Tinggi Agama Islam Negeri Jurai Siwo Metro Lampung e-mail: zainaltob@yahoo.co.id

\begin{abstract}
The Integration of secience in Islamic tradition is importance aspect. In the Islamic historical contect indicated that Islamic education was supported to integration of secience, because more of islamic education institution can be important playing in developing aspect especially to built the civiulization araound the world. From early Islam period, many institution of Islamic education was produced several Islamic intellectuals heritage and more Islamic scholars, so its developed sciences of Islamic perspectives. This tradition is a branch of muslim identity who has influenced for many ages. After Islam be came the ones of gread religion in the world,its tradition was established and until now the influence of Islamic tradition in scientific method must be developed and be come to the great interests between Islamic scholars in many Islamic countries.
\end{abstract}

\begin{abstract}
Abstrak
Integrasi ilmu adalah aspek penting dalam tradisi Islam. Sejarah Islam menunjukkan bahwa pendidikan Islam selalu didukung dengan integrasi ilmu, karena itu lembaga pendidikan Islam dapat lebih banyak memainkan peranan penting dalam mengembangkan berbagai aspek untuk membangun dunia. Sejak awal periode Islam, banyak lembaga pendidikan Islam menghasilkan beberapa warisan intelektual Islam dan ulama, sehingga berbagai ilmu dapat dikembangkan dari perspektif Islam. Tradisi ini merupakan identitas muslim yang berpengaruh selama berabad-abad yang harus selalu dikembangkan
\end{abstract}

Kata Kunci : Tradisi Ilmu, institusi Islam, sejarah, intelektual, pengembangan sains.

* Penulis adalah Dosen STAIN Jurai Siwo Metro Lampung, alumnus Program S3 UIN Syarif Hidayatullah Jakarta tahun 2008 


\section{A. PENDAHULUAN}

Isu tentang pentingnya integrasi ilmu yang diwacanakan pada era modern tidak bisa dilepaskan dari sisi historis perkembangan peradaban umat Islam. Mehdi Golshani, seorang sarjana Iran mensinyalir bahwa pertanyaan tentang apa yang dimaksud ilm, dalam pandangan Islam telah muncul sejak masa-masa awal Islam. Beberapa sarjana telah mendefinisikan istilah tersebut secara spesifik pada ilmu-ilmu keislaman. Akan tetapi menurut pendapat banyak sarjana Muslim, istilah tersebut digunakan dalam al-Qur'an dalam pengertian umum dan mencakup spektrum sains yang luas. Dalam pandangan Islam, kriteria keterpujian suatu bidang ilmu adalah kebergunaannya, dan ini berarti bidang ilmu tersebut mampu membawa manusia kepada Tuhan. Bidang ilmu apapun yang memiliki ciri semacam ini adalah terpuji, dan usaha untuk memperolehnya adalah sebentuk ibadah. Dalam hal ini, tidak ada perbedaan antara ilmu-ilmu yang secara spesifik yang bersifat keagamaan dan ilmu-ilmu kealaman. ${ }^{1}$

Secara realitas pengembangan kajian keilmuan dalam Islam diperankan secara meyakinkan dalam dunia pendidikan, terutama peran penting lembaga-lembaga pendidikan sebagai pusat pengkajian berbagai jenis ilmu yang berkembang cukup pasat. Bukan hanya ilmu kajian keagamaan saja melainkan sains dan teknologi yang dianggap canggih pada pada masanya. Kondisi ini juga diperkuat adanya proses integrasi yang diupayakan oleh sejumlah ulama dengan melakukan integrasi bidang agama, filsafat dan sains yang berkembang mada masa itu. Mobilitas yang sangat tinggi para ilmuan Islam dalam pengembangan sains dapat dilacak dari sejarah perkembangan peradaban Islam di Asia dan Eropa yang hingga saat ini bisa disaksikan peninggalan arsitektural, astronomi, botani, kedokteran dan sebagainya. Pada masa kejayaan Islam, pusat-pusat kajian ilmu berkembang cukup pesat dan tersebar dikawasan Asia dan Andalusia (Eropa).

\section{B. SEJARAH TRADISI KEILMUAN DALAM ISLAM}

Dalam perspektif sejarah, penggunaan nalar dalam rangka pengembangan ilmu dalam Islam, di samping tentunya penggunaan porsi wahyu untuk mengimbangi keterbatasan nalar manusia dalam pencarian pengetahuan hakiki, tampaknya menjadi isu yang menarik sejak dari awal kemunculan Islam itu sendiri sebagai sebuah agama yang sangat menghormati pengembangan ilmu. Karena kebenaran wahyu adalah absolut, maka argumen akal (nalar) tentang kebenaran wahyu tidak memberikan pengaruh apapun terhadap sejatinya kebenaran itu. Demikian sebaliknya, argumen akal yang menyatakan ketidakbenaran wahyu tidak lantas membuat wahyu itu menjadi tidak benar. Akan tetapi, apabila akal melakukan penalaran yang valid, maka ia akan sesuai dengan kebenaran wahyu. Kesahihan proses transmisi data autoritatif melahirkan ilmu tafsir dan ilmu hadits yang kemudian berkembang menjadi landasan ilmu-ilmu lainnya. ${ }^{2}$

${ }^{1}$ Mehdi Golshani, Melacak Jejak Tuban Dalam Sains Tafsir Islami atas Sains, terjemahan judul aslinya, Issues in Islam and Science, Cet. I, (Bandung: Mizan, 2004), h.1.

${ }^{2} J u h a y a$ S Praja, Filsafat dan Metodologi Ilmu Dalam Islam, (Bandung: Teraju, 2002), h. 77. Pendapat tersebut mengacu pada Ibnu Taymiyyah dalam buku Minhaj al-Sunnah dan Al-Radd 'ala al-Mantiqiyyin (Mesir: n.d) dan Ibnu Sina, dalam kitab Al-Hidayah, (Kairo: n.d). 
Dengan demikian al-Qur'an dan Sunnah adalah rujukan ilmu-ilmu Islam. Al-Quran merupakan himpunan wahyu yang menjadi dalil ilmu-ilmu. Dalil di sini mengandung arti petunjuk adanya ilmu-ilmu, bukan ilmu itu sendiri. Oleh karena itu sejarah menujukkan fakta bahwa al-Qur'an mendorong umatnya untuk menciptakan ide-ide sains yang menjadi dasar bagi perkembangan ilmu-ilmu di kemudian hari. ${ }^{3}$ Dalam al-Qur'an, kata ilm, atau pengetahuan digunakan baik untuk ilmu-ilmu kealaman maupun jenis ilmu yang lain. Kajian tentang alam direkomendasikan dengan tujuan untuk menemukan pola-pola Tuhan di alam semesta dan memanfaatkannya demi kemaslahatan umat manusia. ${ }^{4}$ Karena sebenarnya ilmu merupakan anugerah yang berasal dari Allah, sebagaimana firman-Nya dalam QS Al-Naml 27:15, sebagai berikut:

\section{ولقد اتينا داود وسليمن علما وقالا الحمد لله الذى فضلنا على كثير من عباده المؤمنين}

Artinya:

Dan sesunggubnya Kami telah memberikan ilmu kepada Daud dan Sulaiman dan keduanya mengucapkan

kata: Segala puji bagi Allah yang melebihkan kami dari kebanyakan hamba-bambanya yang beriman.

(Q.S. Al-Naml, 27 15).

Terhadap ayat tersebut Sayyid Quthb dalam tafsirnya Fi Zhilal al-Qur'an menafsirkan bahwa ilmu yang dimaksud dalam ayat itu adalah ilmu dalam pengertian yang sangat umum, tidak dijelaskan jenis ilmunya. Juga terdapat isyarat bahwa semua jenis ilmu adalah anugerah Tuhan dan setiap pemilik ilmu diharapkan mengenali sumber ilmunya dan mesti berpaling kepada Tuhan serta bersyukur kepada-Nya. Dia juga harus menggunakan ilmunya itu untuk mencapai keridhaan Tuhan, yang telah menganugerahkan ilmu itu kepadanya. Bila ada suatu ilmu yang menyebabkan perpisahan hati seseorang dengan Tuhannya, tidak lain adalah penyimpangan. ${ }^{5}$ Pandangan Sayyid Qutbh ini dapat ditarik pemahaman bahwa ketika terjadi perceraian antara sains dengan sumbernya yaitu wahyu Tuhan atau katakanlah agama, maka bisa dianggap sebagai sebuah penyimpangan, sebagaimana ilmu-ilmu yang telah disekulerkan pada masa modern.

Ilmu-ilmu Islam dibangun atas dasar kebenaran yang bersifat autoritatif (al-naqliyyat wa al-mutawatbirat) yakni para pemegang autoritas di bidangnya melalui data-data yang ditransmisikan secara berkesinambungan, data-data empirik (al-tajribat al-bissiyah) yang meliputi al-hadasiyyat wa al-mujarrabat. Ibnu Sina membedakan antara data empirik yang disebut al-hadasiyyat, dengan pengalaman empirik yang disebut al-mujarrabat. Al-hadasiyyat adalah data empirik yang terjadi di luar kemampuan manusia untuk menciptakannya seperti gerhana, gempa bumi dan sebagainya. Adapun pengalaman empirik (al-mujarrabat) adalah pengalaman yang diciptakan manusia atau dijadikan bahan eksperimen. ${ }^{6}$ Ilmu-ilmu Islam juga dibangun atas dasar kebenaran-kebenaran rasional ('aqliyyah) yang melahirkan ilmu murni, dan dibangun pula atas dasar pengetahuan intuitif (al-Kasyfiyyah). Pengetahuan

\footnotetext{
${ }^{3}$ Juhaya S Praja, Filsafat dan Metodologi, h. 76

${ }^{4}$ Mehdi Golshani, Melacak Jejak Tuhan, h. 4.

${ }^{5}$ Sayyid Quthb, Fi Zhilal al-Qur'an, (Beirut: Dar Ihya' al-Turats al-'Araby, 1386H), h. 262-263.

${ }^{6}$ Juhaya S. Praja, Filsafat dan Metodologi, h.76-77
} 
terakhir inilah yang memungkinkan lahirnya ilmu tasawuf praktis, di samping tasawuf falsafi dan tasawuf ilmiah. ${ }^{7}$

Dalam perspektif sejarah sains (science) modern, asal-usul sains modern atau revolusi Ilmiah, berasal dari peradaban Islam. Memang sebuah fakta, umat Islam adalah pionir sains modern. Jikalau mereka tidak berperang di antara sesama mereka, dan jika tentara Kristen tidak mengusirnya dari Spanyol, dan jika orang-orang Mongol tidak menyerang dan merusak bagian-bagian dari negeri-negeri Islam pada abad ke-13, mereka akan mampu menciptakan seorang Descartes, Gassendi, Hume, Copernicus, karena kita telah menemukan bibit-bibit filsafat mekanika, empirisme, elemen-elemen utama dalam heliosentrisme, dan instrumen-instrumen Tycho Brahe, dalam karya-karya al-Ghazali, Ibnu Shathir, para astronom pada observatorium Maragha, dan karya-karya Takiyyuddin. ${ }^{8}$

Menurut Mulyadi Kartanegara bahwa kata science, sebenarnya dapat saja diterjemahkan dengan ilmu. Seperti science, kata ilm dalam epistemologi Islam, tidak sama dengan pengetahuan biasa saja, tetapi seperti yang didefinisikan oleh Ibnu Hazm (w.1064), ilmu dipahami sebagai "pengetahuan tentang sesuatu sebagaimana adanya", dan seperti science dibedakan dengan knowledge, ilmu juga dibedakan oleh ilmuwan muslim dengan ra'y (opini). Akan tetapi, di Barat ilmu dalam pengertian ini telah dibatasi hanya pada bidang-bidang ilmu fisik atau empiris, sedangkan epitemologi Islam, ia dapat diterapkan dengan validnya, baik pada ilmu-ilmu yang fisik empiris maupun non-fisik atau metafisis. Dalam buku Ihsha al-Ulum (klasifikasi ilmu), Al-Farabi (w.950) memasukkan ke dalam klasifikasi ilmunya bukan hanya ilmu-ilmu empiris, seperti fisika, botani, mineralogi, dan astronomi, melainkan juga ilmu-ilmu non-empiris, seperti matematika, teologi, kosmologi dan metafisika. Oleh karena itu pada dasarnya kata science diterjemahkan sebagai ilmu, dengan syarat bahwa ilmu dalam epistemilogi Islam tidak dibatasi pada hanya pada bidang-bidang fisik seperti dalam epistemologi Barat. ${ }^{9}$

Berbeda dengan pandangan epistemologi Barat, para ilmuwan Muslim berpendapat bahwa manusia bisa mengetahui bukan hanya obyek-obyek fisik, melainkan juga obyekobyek non-fisik. Oleh karena itu, dalam epistemologi Islam bisa dikenal entitas-entitas nonfisik, seperti konsep-konsep mental dan metafisika, di samping entitas-entitas fisik. Demikian juga tidak mustahil bagi kita untuk mengetahui makhluk-makhluk halus, seperti jin, malaikat, dan ruh, di samping benda-benda fisik yang kita jumpai. ${ }^{10}$ Dengan demikian kekayaan epistemologi Islam bukan saja menghargai fenomena alam (natural), tetapi juga menoleransi pengalaman-pengalaman fenomenal dari perspektif supranatural.

Dari kerangka berpikir seperti inilah, epistemologi Islam telah berhasil menyusun "kalsifikasi ilmu", yang komprehensif dan disusun secara hierarkhis, yaitu metafisika

${ }^{7}$ Juhaya S Praja, Filsafat dan Metodologi, h. 76

${ }^{8}$ Cemil Akdogan, Asal-Usul Sains Modern dan Kontribusi Islam, dalam Majalah Pemikiran dan Peradaban Islam, Islamia, Th 1 No 4, Januari-Maret 2005, (Jakarta: Islamia, 2005), h. 94.

${ }^{9}$ Mulyadhi Kartanegara, Menembus Batas Waktu, Panorama Filsafat Islam, (Bandung: Mizan, 2002), cet. I, h. $57-56$

${ }^{10}$ Mulyadhi Kartanegara, Menembus Batas Waktu, h. 59. 
menempati posisi tertinggi, disusul oleh matematika dan terakhir ilmu-ilmu fisik, ${ }^{11}$ sehingga membentuk sebuah "trikhotomik" ilmu (metafisika, matematika, ilmu-ilmu fisik). Kemudian dari deskripsi trikhotomik seperti itu, lahir berbagai disiplin ilmu rasional dalam Dunia Islam, seperti ontologi, teologi, kosmologi, angelologi, dan eskatologi yang termasuk ke dalam kategori ilmu-ilmu metafisika, geometri, aljabar, aritmetika, musik, dan trigonometri, yang termasuk ke dalam kategori ilmu-ilmu matematika dan fisika, kimia, geologi, geografi, astronomi, optika, dan sebagainya yang masuk dalam kategori ilmu-ilmu fisik. ${ }^{12}$

Banyak ilmuwan modern pada realitasnya hanya percaya pada kenyataan yang bisa diamati, diuji dan diukur dalam pengembangan epistemologi ilmu. Kebanyakan mereka sangat apresiatif dan hanya percaya pada "keberadaan" benda-benda yang bisa dicerap oleh indera, dan oleh karena itu cenderung menolak status ontologis dari entitas-entitas non-fisik, seperti ide-ide matematika, konsep-konsep mental dan entitas imajinal dan spiritual, yang disebut oleh para filosof sebagai ma'qulat (intelligibles). Sebaliknya ilmuwan Muslim mengakui status ontologis bukan hanya dari obyek-obyek inderawi (mabsusat), melainkan juga obyek-obyek non-inderawi (ma'qulat $)^{13}$

Dengan demikian perbedaan perpektif tersebut berimplikasi pada perbedaan metodologi yang digunakan dalam pengembangan ilmu. Metode ilmiah yang dikembangkan oleh pemikir Muslim berbeda secara signifikan dengan metode ilmiah yang dikembangkan oleh pemikir Barat. Sebab seperti pernah dikatakan oleh Ziauddin Sardar, sementara para ilmuwan Barat menggunakan hanya satu macam metode ilmiah, yaitu metode observasi, para pemikir Muslim menggunakan tiga macam metode sesuai dengan tingkat atau hirarkhi obyek-obyeknya, yaitu; (1) metode observasi sebagaimana digunakan Barat yang disebut "bayani", (2) metode logis atau demonstratif ("burbani") dan metode intuitif (“irfan`"), yang masing-masing bersumber pada indra, akal dan hati. ${ }^{14}$

Para ilmuwan Barat berhenti pada bidang-bidang fisik dalam penelitian ilmiah mereka, sebaliknya para ilmuwan-ilmuwan Muslim yang sekaligus filosof, meneruskan kajian ilmiah mereka ke bidang-bidang non-fisik, baik yang bersifat matematis maupun metafisis. Pada umumnya para ilmuwan Muslim inilah yang memiliki kemampuan kolaboratif dalam menangkap makna-makna dari obyek-obyek inderawi, sekaligus menangkap makna dari obyek-obyek non-inderawi. Karena mereka menyadari bahwa hasil observasi yang dilakukan indra bisa saja keliru, sehingga dibutuhkan verifikasi terhadap hasil-hasilnya. Demikian juga hasil penelitian akal bisa saja keliru kalau tidak mengikuti alur dan aturanaturan berpikir yang benar yang disebut logika. ${ }^{15}$

\footnotetext{
${ }^{11}$ Osman Bakar, Hierarki Ilmu: Membangun Rangka Pikir Islamisasi Ilmu, (Bandung: Mizan, 1997), h. 120131.

${ }^{12}$ Mulyadhi Kartanegara, Menembus Batas Waktu, h. 59.

${ }^{13}$ Mulyadhi Kartanegara, Menembus Batas Waktu, h. 59-60.

${ }^{14}$ Mulyadhi Kartanegara, Menembus Batas Waktu, h. 61. Lihat juga H.S. Nasr, "Mulla Shadra: His Teaching” dalam Nasr dan Oliver Leaman, History of Islamic Philosophy, Jilid I, (London:Routledge, 1996), h. 644.

${ }^{15}$ Mulyadhi Kartanegara, Menembus Batas Waktu, h. 62.
} 
Keberadaan logika sebenarnya diperkenalkan oleh Aristoteles dan merupakan metode ilmiah yang mengggunakan akal atau rasio dalam memahami obyek-obyek non-fisik. Meskipun demikian, para filosof mengakui adanya beberapa tingkatan atau jenis dari metode logis, dilihat dari keakuratannya, yaitu metode poetika (syi $r$ ), retorika (khitabi), dan dialektika (jadali), sofistika (mughalithi) dan metode demosntratif (burbani). Metode demonstratif dipandang sebagai metode yang paling ilmiah, yang diharapkan dapat menagkap realitas obyek-obyek yang ditelitinya dengan tepat, karena telah terhindar dari kekeliruan-kekeliruan logis (logical fallacies), sebagaimana dialektika yang dikembangkan dalam perspektif filsafat logika yakni teknik menyusunan premis-premis dalam sebuah silogisme. ${ }^{16}$

Ada asumsi bahwa tradisi intelektual Muslim terutama di dunia Sunni telah lama mati. Namun di dunia Muslim Syi'ah, yang merupakan kelompok minoritas di antara mayoritas Sunni, tradisi intelektual tersebut terus hidup dan dikembangkan dari abad ke abad oleh sederetan panjang filosof dan ilmuwan Syi'ah, hingga sekarang. Karena di sebagian besar kalangan masyarakat Muslim Sunni masih sangat kuat dipengaruhi oleh anggapan bahwa mempelajari filsafat adalah dilarang dan berdosa hukumnya, sementara di kalangan cendekiawan Muslim Syi'ah tradisi pengkajian filsafat tetap terpelihara. Hasilnya sangat menakjubkan, sebab pada saat sulit menemukan seorang filosof di masa modern ini di dunia Sunni, namun di kalangan Syi'ah dapat ditemukan tokoh fislafat modern yang lahir, terutama pada abad ke-20. Di antaranya, seperti Murthada Mutahari, Thaba'thaba'i, Jalal al-Din Asythiyani, Mehdi Hairi Yazdi, dan sebagainya yang secara aktif merespon tantangan filosofis dan ideologis Barat. Ini tercermin misalnya dari karya Thaba'thaba'i, The principle of Philosophy and Realistic Method, yang telah secara sistematik dan terperinci mengkritik dan menggoyahkan dasar-dasar filosofis Marxisme. ${ }^{17}$

Dengan demikian dapat diketahui bahwa tradisi intelektual Islam belumlah sirna, tetapi tersimpan rapi dalam karya-karya ilmiah filosofis agung para pemikir Syi'ah. Karyakarya filsafat peripatetik Muslim, seperti al-Farabi, Ibnu Sina, Ibnu Rusyd terlestarikan, baik dalam bentuk aslinya, maupun dalam bentuk komentar-komentar oleh para filosof sesudahnya-seperti Nashir al-Din Thusi dan Mulla Shadra. Demikian juga karya-karya filosofis Isyraqiyah (iluminasionis), warisan Suhwardi dan pengikutnya, seperti Syams alDin Syahrazuri (w. 1288M), Quthb al-Din Al-Syirazi (w.1311M), dan Mir Damad (w. $1631 \mathrm{M}$ ) terus terlestarikan, baik dalam bentuk tulisan maupun tradisi lisan pada forumforum kajian tradisional yang terus berlangsung sampai hari ini. ${ }^{18}$

Selain madzhab tradisional di atas, warisan agung dari tradisi mistik, terutama Ibnu 'Arabi dan Jalaluddin Rumi, juga begitu diakrabi oleh pemikir Syi'ah pasca Ibnu Rusyd, dari Baba Afdhal (w.1213M), al-Hilli (w. 1325M), al-Amuli (w. 1385), Ibnu Turkah (w. 1432M), sampai Mir Damad dan Findiriski (w. 1641M). Dan yang paling mengagumkan adalah munculnya tokoh besar setelah Ibnu Rusyd, yakni Shadr al-Din al-Syirazy (w.

\footnotetext{
${ }^{16}$ Mulyadhi Kartanegara, Menembus Batas Waktu, h. 63-64.

${ }^{17}$ Mulyadhi Kartanegara, Menembus Batas Waktu, h. 102-103.

${ }^{18}$ Mulyadhi Kartanegara, Menembus Batas Waktu, h. 103.
} 
1641M), yang lebih dikenal dengan Mullah Shadra, yang telah berhasil bukan saja melestarikan ketiga arus pemikiran tersebut yaitu, Peripatetik, Iluminationis dan Mistik, dan berhasil mensintesakan ketiga-tiganya dalam sebuah eksposisi filosofis yang agung dan sangat sistematik. Maha karyanya al-Asfar al-Arba'ab telah menandai puncak pencapaian filosofis Islam. Sedangkan sintesis agungnya telah membawa filsafat Islam ke tahap berikutnya, yaitu "Teosofi Transseden" (al-Hikmah al-Muta'aliyah), yang dapat dibedakan dari tahap-tahap sebelumnya yaitu Peripatetik-Iluminasionis. Tradisi pemikiran Shadrian telah dikembangkan oleh kedua muridnya al-Lahji (w. 1661 M), dan al-Kasyani (w. 1680 M), yang kebetulan keduanya adalah menantu Mullah Shadra.

Tradisi intelektual itu terus dikembangkan pada abad-abad berikutnya oleh para filosof Syi'ah lainnya, yang tidak kalah pentingnya sebagai mata rantai tradisi yang panjang ini, seperti Ahmad Ansha’i (w. 1820 M), Mulla Hadi Sabzawari (w. 1878 M), dan muridnya, Mirza Ali Akbar Yazdi merupakan salah seorang guru filsafat Ayatullah Khomaeni (w.1988 M). Jadi melalui Mulla Hadi Sabzawari, dan muridnya tersebut, tradisi intelektual Islam diantar ke pintu gerbang abad ke-20, dan telah melahirkan puluhan filosof besar Syi'ah kontemporer. Tradisi ini, di dunia modern Syi'ah merupakan tradisi yang hidup dan dikaji dalam beberapa lembaga kajian tradisional dan modern. Jadi sementara tradisi intelektual di dunia Sunni telah lama mati, justru di dunia Sy'iah tradisi intelektual tersebut, masih hidup dan berkembang. ${ }^{19}$

Dengan begitu sebenarnya tradisi intelektual Islam tetap terjaga dan terlembagakan dengan mapan (establisment) dalam konstruk pemikiran filosof Muslim Syi'ah. Sementara itu di kalangan Muslim Sunni, tradisi intelektual tersebut telah mengalami kemandegan (stagnasi) pemikiran yang luar biasa. Sebagaimana pendapat yang dikemukakan oleh Abudddin Nata yang menyatakan bahwa dalam perkembangan selanjutnya konsep ilmu pengetahuan Islam dalam khazanah intelektual Islam pada masa kemudian memperlihatkan sifatnya yang dikhotomis, yaitu suatu keadaan dimana antara ilmu agama dengan ilmu pengetahuan umum terkesan terpisah, berjalan sendiri-sendiri tanpa mengenal hubungan secara substansial. Keadaan ini membawa akibat timbulnya sikap mengagungkan suatu ilmu dan merendahkan ilmu lainnya. ${ }^{20}$

Terjadinya sifat ilmu yang dikhotomis tersebut di atas selanjutnya sering dihubunghubungkan dengan upaya al-Ghazali yang membagi ilmu pengetahuan menurut paradigma fiqih, yaitu adanya ilmu yang termasuk dalam kategori fardlu 'Ain, fardlu kifayah dan mubah. Ilmu Fikih dan aqidah misalnya termasuk ke dalam ilmu fardlu 'ain. Semua orang Islam wajib belajar ilmu ini dan sekaligus mengamalkannya, karena kedua ilmu ini di nilai bisa membawa manusia mampu berhubungan dengan Allah SWT dan menyakini-Nya secara benar menurut syari'at. Sementara itu ilmu matematika, kedokteran dan sejenisnya dimasukkan dalam kategori ilmu fardlu kifayah. Semua orang Islam tidak wajib mempelajari ilmu ini, melainkan cukup jika ada salah seorang di antara mereka yang mempelajarinya.

\footnotetext{
${ }^{19}$ Mulyadhi Kartanegara, Menembus Batas Waktu, h. 105.

${ }^{20}$ Abuddin Nata, Konsep Pendidikan Ibnu Sina, Disertasi pada Program Pascasarjana IAIN Syarif Hidayatullah Jakarta, 1997 (Jakarta: IAIN, 1997), h. 43.
} 
Selanjutnya ilmu ketangkasan fisik, bela diri dan sejenisnya dimasukkan ke dalam kelompok ilmu yang mubah, yakni boleh saja mempelajari ilmu ini jika memerlukannya. Akibatnya sebagian orang ada yang mengutamakan ilmu tertentu saja. ${ }^{21}$

Menurut Abuddin Nata, secara rinci di dalam kitab Ibya'Ulumuddin, Al-Ghazali secara panjang lebar menjelaskan tentang pembagian ilmu pengetahuan. Hal itu juga dilakukan oleh para ahli filsafat yang membagi ilmu menjadi beberapa cabang dan macamnya. Mengenai yang dimaksud ilmu yang fardlu (wajib), Al-Ghazali menjelaskan bahwa ilmu tersebut wajib dipelajari oleh semua orang Islam, yakni ilmu agama, ilmu yang bersumber dari kitab suci Allah. Kemudian ilmu yang merupakan fardlu kifayah untuk dipelajari setiap muslim. Ilmu ini adalah ilmu yang dimanfaatkan untuk memudahkan urusan hidup duniawi, misalnya ilmu hitung (matematika), ilmu kedokteran, ilmu teknik, ilmu pertanian dan industri. $^{22}$

Dalam mengajarkan ilmu pengetahuan kepada anak didik, al-Ghazali menekankan pentingnya mengajarkan ilmu pengetahuan dari kandungan kitab suci al-Qur'an sendiri. Hal ini karena ilmu yang diajarkan oleh al-Qur'an dapat bermanfaat untuk kehidupan manusia di dunia dan akhirat, yaitu memperkuat jiwa dan memperindah ahklak serta mendekatkan diri kepada Allah SWT. Sebaliknya ilmu bahasa dan gramatika hanya berguna untuk mempelajari ilmu agama atau berguna dalam keadaan darurat saja. Sedangkan ilmu kedokteran, matematika, dan teknologi hanya bermanfaat bagi kehidupan manusia dilihat dari segi kebudayaan bagi kesenangan berilmu serta sebagai kelengkapan dalam hidupnya. ${ }^{23}$

Tradisi intelektual dan integrasi keilmuan yang menjadi konsens para ilmuan klasik, seperti klasifikasi ilmu yang dikembangkan oleh ulama-ulama klasik tersebut mengindikasikan sebuah kesadaran tentang pentingnya pengembangkan keilmuan yang menduklung pengembangan peradaban Islam pada masa-masa selanjutnya. Kondisi ini juga dibarengi dengan pengembangan sistem pendidikan Islam yang dapat ditelusuri dalam konteks historis, yakni sebuah ikhtiar para pemikir muslim unruk mengembangkan ilmu dalam berbagai institusi pendidikan Islam. Usaha itu dilakukan secara kontinyu oleh para pakar pendidikan Islam, melalui jalur transmis intelektual dari generasi ke generasi berikutnya. Secara empiris institusi atau lembaga-lembaga pendidikan inilah yang banyak berperan dalam pengembangan dan sekaligus penjaga tradisi intelektual Islam hingga sekarang.

\section{PERANAN LEMBAGA PENDIDIKAN DALAM PENGEMBANGAN SAINS}

Tidak bisa dipungkiri bahwa pengembangan sains dalam diskursus sejarah Islam tidak bisa dilepaskan dari peranan para ilmuwan yang berkiprah di beberapa lembaga pendidikan yang mengembangkan teori ilmu sekaligus mentransmisikan teori-teorinya

\footnotetext{
${ }^{21}$ Abuddin Nata, Konsep Pendidikan Ibnu Sina, h. 43-44.

${ }^{22}$ Muzayyin Arifin, Filsafat Pendidikan Islam, (Jakarta: Bumi Aksara, 2003), h. 80.

${ }^{23}$ Muzayyin Arifin, Filsafat Pendidikan Islam, h. 81.
} 
tersebut kepada murid-muridnya maupun kepada masyararakat luas. Hal ini sangat menentukan juga terhadap corak pemikiran yang dikembangkan para ulama pada masa klasik Islam. Dengan demikian melacak pertumbuhan lembaga pendidikan pada masa awal Islam menjadi sangat penting untuk mencari kronologis pertumbuhan dan pengembangan ilmu dalam perspektif sejarah Islam.

Pada abad sebelum Nabi Muhammad SAW menyampaikan wahyu yang diterimanya kepada sekretarisnya, sekolah telah dikenal di kota-kota utama Arab, terutama Mekkah. Menurut Syalaby, mencatat bahwa orang asli Mekkah yang pertama mengenal tulis-baca kebanyakan diajarkan oleh orang Kristen dan bahwa jumlah orang Mekkah yang mengenal tulis baca pada saat datangnya Islam adalah 17 orang. ${ }^{24}$ Bahkan pada masa awal Islam, orang Kristen tetap menjadi guru tulis baca, sebab orang Muslim yang bisa baca hanya sedikit. Mereka yang sedikit ini dipekerjakan sebagai juru tulis al-Qur'an sebagaimana didektekan oleh Nabi Muhammad dan melakukan penyalinan ulang agar dapat disebarluaskan ke daerah-daerah taklukan yang semakin luas. ${ }^{25}$

Meskipun belakangan para pakar tentang Arab berpandapat bahwa sekolah dasar yang disebut kuttab, mulai dikenal pada masa awal Islam, untuk pendidikan anak tentang al-Qur'an dan isinya. Shalaby berpandangan bahwa kuttab lebih terfokus pada pengajaran tulis baca. Pada dasarnya pengajaran ajaran Islam secara natural berlangsung di lembagalembaga Islam baru yaitu masjid. ${ }^{26}$ Dengan demikian bagi kebanyakan anak-anak Muslim pada abad pertama, pendidikan formal terdiri dari pendidikan di kuttab untuk belajar tulis baca, menggunakan puisi Arab sebagai buku pelajaran. Sementara pendidikan agama terpusat pada bacaan al-Qur'an dan artinya terpusat dalam masjid-masjid setempat. Pendidikan agama mendapat tempat di kuttab hanya bila seorang guru kuttab adalah orang yang hafal al-Qur'an ${ }^{27}$

Sumber-sumber yang ada tidak selalu sependapat tentang lokasi kuttab. Jelas bahwa kuttab bisa terdapat di rumah-rumah tinggal, dimana seorang guru mengumpulkan muridmuridnya dalam satu ruangan di dalam rumah, atau tempat terbuka di luar rumah. Beberapa sumber mengatakan bahwa guru memanggil muridnya ke lapangan sekitar masjid atau taman umum. Walaupun pengajaran al-Qur'an atau ilmu-ilmu agama pada level yang lebih tinggi berlangsung di masjid. Kegiatan kuttab, karena mengajarkan anak-anak yang jauh lebih muda, tidak dilaksanakan di dalam masjid. Alasannya bahwa anak-anak terlalu kacau dan ribut untuk diizinkan dalam masjid. Dengan demikian eksistensi dan fungsi kuttab adalah sebagai lembaga pendidikan dasar yang berkembang pada saat awal Islam.

Pada abad-abad awal Islam, masjid muncul sebagai pusat pendidikan lanjutan dan pendidikan tinggi bagi remaja dan orang dewasa dalam ilmu-ilmu agama. Sebagai tempat belajar, masjid menyediakan perlindungan dan mengundang setiap orang alim

${ }^{24}$ Ahmad Syalaby, History of Muslim Education, (Beirut: Dar al-Kasshaf, 1954), h. 16.

${ }^{25}$ Charles Michael Stanton, Pendidikan Tinggi Dalam Islam, terjemahan dari Higher Learning in Islam, penerjemah H.Affandi dan Hasan Asari, (Jakarta: Logos, 1994), h. 18.

${ }^{26}$ Ahmad Syalaby, History of Muslim Education, h. 16-17.

${ }^{27}$ Charles Michael Stanton, Pendidikan Tinggi, h. 19. 
mengumpulkan orang-orang di sekelilingnya untuk membaca al-Qur'an dan mendiskusikan pesan-pesan serta persoalan-persoalan agama lainnya. Meski tidak terstruktur, kelompok belajar yang disebut halaqah, kemudian berkembang menjadi formal, beberapa di antaranya berlangsung dalam beberapa dekade. ${ }^{28}$ Halaqah membentuk lingkaran yang mengelilingi seorang syaikh halaqah yang dengan kefasihan bahasa dan bicaranya serta kedalaman ilmu pengetahuannya, dapat menarik pendengar. Pada awalnya seorang syaikh halaqah, secara alami dan statusnya ditentukan oleh pengikutnya sendiri. Belakangan, dengan persiapan formal, seorang syaikh halaqah dapat diangkat menjadi pengurus masjid. Pengunjung halaqah yang datang secara sukarela bebas memilih halaqah yang ia senangi dan datang atau pergi sesuka hatinya. Syaikh yang sangat populer bisa menghimpun sekelompok pengikut yang mengidentifikasikan diri kepadanya. Materi pengajaran dalam halaqah dipilih untuk memenuhi kebutuhan pesertanya dalam pencarian makna al-Qur'an yang lebih dalam. Halaqah juga membantu mengokohkan keimanan Muslim dan mendorong mereka untuk hidup secara lebih religius. ${ }^{29}$

Berbagai halaqah dalam satu masjid menawarkan pelajaran dalam beragam disiplin mencakup hadits, tafsir, fiqih, ushul fiqih, nahu, sharaf, dan sastra Arab. Disiplin-disiplin yang dianggap bukan ilmu agama tidak termasuk dalam kegiatan pengajaran para syaik $h$ halaqah di masjid. Semua buku filsafat Yunani, sains, dan disiplin-disiplin sekuler lainnya yang berasal dari Timur tidak diajarkan di sana. Besar kecilnya satu halaqah tergantung pada popularitas syaikh yang memimpin kajian, dan bidang kajian yang ditawarkan. Biasanya balaqah terdiri dari 10 hingga 20 orang Murid. ${ }^{30}$ Murid-murid halaqah tidak perlu membayar uang sekolah dan sama sekali tidak ada peraturan tentang di mana mereka harus tinggal atau bekerja. Mereka bebas datang dan pergi sesuka hati dan memilih pelajaran yang mana saja yang diminati. Begitu juga mereka bebas pindah dari halaqah satu ke halaqah lainnya, serta dari masjid satu ke masjid lainnya, serta dari kota satu ke kota lainnya. Baik guru maupun murid menikmati kebebasan akademik dalam menelusuri satu persoalan, sejauh tidak menimbulkan bid'ah. Diskusi, debat dan pandangan-pandangan baru didorong perkembangannya dalam kerangka kerja ajaran Islam. ${ }^{31}$

Langkah strategis perkembangan lembaga pendidikan tinggi Islam berikutnya terjadi di bawah patronase wazir Nizamul Mulk, sekitar 1064. Bangunan baru yang disebut madrasah, yang meniru model masjid-akademi yang memiliki asrama (masjid-khan). Istilah Khan dapat diterjemahkan sebagai pemondokan-penginapan musafir-tetapi dalam hubungan ini, istilah tersebut berarti asrama mahasiswa yang berasal dari desa-desa yang jauh, yang pada umumnya belajar fiqh. ${ }^{32}$ Praktik penyediaan tempat tinggal yang

${ }^{28}$ Charles Michael Stanton, Pendidikan Tinggi, h. 23-24.

${ }^{29}$ Charles Michael Stanton, Pendidikan Tinggi, h. 24.

${ }^{30}$ George Makdisi, The Rise of Colleges, (Edinburgh: Edinburgh University Press, 1981), h. 170.

${ }^{31}$ Charles Michael Stanton, Pendidikan Tinggi, h. 37.

${ }^{32}$ Asrama Mahasiswa, diperkenalkan oleh seorang bangsawan kaya, terkenal pada abad ke-10 yang bernama Badr Ibn Hasanawayh al-Kurdy (w.1015), seorang gubernur di beberapa wilayah. Reputasinya sebagai seorang dermawan yang membantu jama'ah haji yang dalam perjalanan dan para ilmuwan. Dalam 
menyatukan guru dan murid di satu kompleks berlanjut terus sepanjang sejarah pendidikan tinggi baik di Timur maupun di Barat. Hal ini mendorong terciptanya atmosfir di mana pendidikan diperkuat oleh situasi yang hidup dan oleh keuntungan besar dari munculnya komunitas ilmiah.

Madrasah dapat disebut juga sebagai akademi (college), sebagaimana yang ada sekarang. Pada masa Turki Saljuq telah mengambil alih pemerintahan Timur Tengah dari kekhalifahan Abassiyah. Bani Saljuq berasal dari Asia Tengah yang kemudian berpindah ke Barat, sambil melakukan Islamisasi sepanjang perjalanan. Sebelum menyerang Baghdad, pemimpin Saljuq menyetujui untuk tidak menghapus otoritas keagamaan Khalifah, tetapi hanya membentuk pemerintahan politik di bawah pimpinan salah seorang dari keluarga Saljuq yang akan memakai gelar "Sultan". Nizamul Mulk adalah seorang Wazir yang berkuasa, atau Perdana Menteri sang Sultan. Untuk menjamin kelangsungan kekuasaannya. Nizamul Mulk membantu pembangunan ratusan madrasah yang mengajarkan fiqih dalam madzhab Syafi'i. ${ }^{33}$

Dalam membangun madrasah wazir Nizamul Mulk menyediakan wakaf untuk membiayai seorang mudaris, seorang imam, dan juga mahasiswa yang menerima beasiswa atau fasilitas asrama. Beasiswa untuk mahasiswa ini merupakan perbedaan antara madrasah dan masjid-akademi, sebab dengan demikian madrasah lebih menarik bagi mahasiswa dari keluarga yang tidak mampu. Ini adalah asal-muasal dari penyediaan tempat tinggal bagi ilmuwan-ilmuwan miskin di universitas-universitas-praktek yang pada abad pertengahan barat berakar kuat di Paris, Oxford dan Cambridge. ${ }^{34}$ Madrasah juga mempunyai satu perpustakaan, yang tergabung dalam satu bangunan yang sama. Walaupun perpustakaan telah lama terdapat di istana dan rumah-rumah bangsawan, dan hartawan. Perpustakaan sebagai bagian dari masjid-akademi adalah hal yang jarang.

Untuk menyediakan manuskrip bagi mahasiswa, madrasah mencontoh praktek halaqah-balaqah, gerakan rasional yang telah terpengaruh oleh budaya Helenistik dan berkembang pesat pada masa pemerintahan Abasiyyah. Tersedianya berbagai karya lebih dari sekadar buku-buku pelajaran meningktakan pengalaman belajar mahasiswa dengan memperkenalkan sejumlah tulisan, dan sejumlah pandangan, lebih dari sekedar kebutuhan langsung perkuliahan.

Pembangunan madrasah dengan dana Wakaf berlanjut sepanjang masa klasik peradaban Islam. Di provinsi al-Andalus, semenanjung Iberia, madrasah tidak dikenal. Oleh karena daerah ini menganut madzhab Malik yang lebih konservatif dan tradisional, hukum wakafnya tidak membenarkan seorang pemberi wakaf untuk mempengaruhi

hal ini memperkenalkan satu elemen dalam pendidikan tinggi Islam yakni Asrama mahasiswa. Badr telah mendirikan 3000 masjid-akademi yang masing-masing memiliki asrama (Masjid-Khan). George Makdisi, "On The Origin and development of The Colleges in Islam and The West", dalam Khalil E Semaan (ed.), Islam and Medieval West, (Al-Bany: Suny Press, 1980, h. 32-33. Lihat juga Charles Michael Stanton, Pendidikan Tinggi, h. 44-45.

${ }^{33}$ Charles Micheal Stanton, Pendidikan Tinggi, h. 46.

${ }^{34}$ Charles Michael Stanton, Pendidikan Tinggi, h. 47. 
pengangkatan syaikh atau penggantinya. Konsekuensi tak terelakkan dari aturan ini adalah kurangnya minat para hartawan untuk mendukung pusat-pusat pendidikan Tinggi. Rangsangan untuk membangun pendidikan tingggi justru berasal dari keluarga penguasa, biasanya Khalifah yang menjadi patron utama lembaga pendidikan tinggi di Granada, Seville, dan Cordova. Walaupun fiqih tetap menjadi bagian inti kurikulum, terutama madzhab Malik, dibanding dengan madzhab lainnya. Tenaga pengajar dan kurikulum berada di bawah kontrol dan keinginan Khalifah dan para penasehatnya. Oleh karena dana bagi pendidikan tingggi disediakan oleh penguasa Andalus, lembaga pendidikan mengalami kemajuan atau kemunduran sesuai dengan perhatian yang diberikan oleh penguasa. Bangsa Moor Spanyol berpengaruh atas Eropa Barat lebih besar dari pengaruh Timur Tengah. Model pendidikan Tinggi al-Andalus berpindah ke Sisilia. Dari sana ke semenanjung Italia sepanjang abad ke-12. Di Italia, contoh al-Andalus ini dijadikan sebagai model bagi kajian Hukum Romawi dan Hukum Agama yang merupakan fakultas paling penting dari Universitas abad pertengahan Eropa Selatan. ${ }^{35}$

Madrasah terbesar yang dibangun oleh Nizamul Mulk di Baghdad adalah Madrasab Nizamiyah. Pendirian madrasah ini tidak bisa dilepaskan dari gerakan doktrinal Mazhab Syafi'i, yang dikenal juga sebagai pendukung gerakan As'ariyah, dan berusaha menggabungkan elemen-elemen yang berasal dari pendekatan liberal maupun konservatif terhadap al-Qur'an. Nizamul Mulk dengan memanfaatkan lembaga wakaf membantu lembaga pendidikan dalam memperkenalkan pandangan Asy'ariyah dan mempelopori pembangunan madrasah Syafi'iyah di seluruh penjuru kekuasaan Saljuq. Meskipun orientasinya sangat religius, madrasah bukanlah masjid secara resmi. Dengan mendirikan lembaga madrasah yang terlihat lebih independen sebenarnya Nizamul Mulk memastikan bahwa dia bisa mengatur kurikulum dan pengangkatan staf. Dengan memisahkan asrama mahasiswa dari masjid, ia membebaskan lembaga ini dari kontrol keagamaan secara langsung (pemerintah), tetapi di saat yang sama tetap berada dalam arus utama masyarakat yang berorintasi keagamaan. Madrasah melambangkan keunikan dari sebuah lembaga pendidikan tinggi pribadi (swasta).

Patron-patron lain mengikuti langkah Nizamul Mulk. Pada abad ke 11, pola dasar pembangunan lembaga pendidikan tinggi yang terpisah dari masjid, dengan implikasi kontrol otoritas keagamaan yang melekat padanya, namun tetap diabdikan kepada pandangan teologis tertentu. Dalam hal ukuran kurikulum, dan pengajaran madrasah sama dengan masjid. Perbedaaanya adalah kemandirian madrasah dari kontrol langsung otoritas kagamaan dan penyediaan beasiswa untuk para mahasiswa, dua hal yang tidak ditemui pada sistem pendidikan masjid di abad-abad sebelumnya. Madrasah Nizamiyah, mengambil nama Nizamul Mulk, berdiri sebagai madrasah paling unggul pada abad ke11. Terletak di pusat kerajaan Seljuk, Nizamiyah menjadi salah satu pusat pendidikan tinggi paling terkenal abad ini, dan menjadi model bagi pembangunan lembaga-lembaga serupa di seluruh daerah kekuasaan Islam. Madrasah ini menjadi corong utama penyebaran madzhab Syafi'i, dan aliran kalam Asy'ariah, yang terus mengalir dalam arus utama dunia

\footnotetext{
${ }^{35}$ Charles Michael Stanton, Pendidikan Tinggi, h. 48.
} 
ilmiah dan pemikiran hukum Islam. Wibawa dan daya tarik al-Ghazali, ilmuwan dan mutakallim, serta sufi abad ke-11 - memudahkan diterimanya Asy'ariyah, tidak saja dengan tulisan dan ceramahnya - tetapi juga dalam peranannya sebagai mudarris, di madrasah terbesar yang dibangun Nizamul Mulk tersebut. ${ }^{36}$

Sejak pembangunannya pada tahun 1067 sampai dengan 1234, madrasah Nizamiyah tetap menjadi lembaga pendidikan tinggi terkemuka di Baghdad. Pada waktu ini Khalifah al-Mustansir mengikuti jejak madrasah Nizamiyah, dan mendirikan sebuah lembaga pendidikan tinggi yang terdiri dari beberapa bangunan yang kemudian digelari dengan nama Khalifah, yakni madrasah al-Mustansiriyah. Madrasah tersebut mencakup empat madrasah, masing-masing mewakili satu madzhab Sunni yang empat. Masing-masing secara terpisah menjalankan pengajaran dan memiliki asrama bagi 62 orang mahasiswa ditambah dengan stafnya. Semua mahasiswa dan staf menerima gaji dari penghasilan wakaf yang disediakan oleh Khalifah. Gambaran tentang gedung ini mengesankan satu gedung yang sangat mewah, penuh ornamen, dan terawat baik. ${ }^{37}$ Dengan dibangunnya al-Mustansiriyah, satu lagi transisi penting terjadi lagi dalam evolusi lembaga pendidikan tinggi Islam, lembaga kecil dengan hanya seorang syaikh, di beberapa kota, beralih menjadi lembaga pendidikan tinggi yang lebih besar dan kompleks. Madrasah-madrasah yang didukung oleh wakaf dalam jumlah besar sekarang cenderung mencakup lebih dari satu madzhab di dalamnya, seperti yang madrasah dibangun oleh Khalifah al-Mustansir itu.

Di samping kota Baghdad yang menjadi pusat pengkajian dan berkumpulnya ulamaulama madzhab yang marak membahas aliran keagamaan. Pada abad ke-12 di kota Jundishapur $^{38}$. Menurut Nakosteen, terdapat beberapa ilmuwan dan dokter yang bermukim di kota tersebut, dan mereka juga terdapat di beberapa kota kota lainnya. Pada umumnya mereka bekerja di rumah sakit dan observatorim, yang berfungsi juga sebagai tempat berteduh bagi para ilmuwan dan dokter yang tidak memperoleh pekerjaan pada lembagalembaga yang beroerientasi keagamaan, seperti masjid dan madrasah. Ilmuwan pada periode ini menulis secara ekstensif, yang mengembangkan pengertian tentang alam dan hubungan antara kehidupan agama, politik dan sosial. Kecuali al-Ghazali, ilmuwanilmuwan zaman ini mengembangkan karirnya di lembaga-lembaga non-formal, tidak di

\footnotetext{
${ }^{36}$ Madrasah Nizamiyah Baghdad, seperti halnya madrasah lain yang dibangun oleh Nizamul Mulk, tetap berada di bawah kontrol Nizamul Mulk selama hidupnya. Dialah yang mengangkat para mudarris, termasuk mengangkat al-Ghazali sebagai salah satu ilmuwan yang direkrutnya menjadi mudarris di madrasah tersebut. Charles Michael Stanton, Pendidikan Tinggi, h. 50.

${ }^{37}$ A.S. Triniton, Muslim Education in the Midle Ages, (London: Luzac, 1957), h. 104.

${ }^{38}$ Jundisapur adalah nama sebuah kota di Kujistan yang dibangun oleh Sabur bin Ardasyir dari kerajaan dinasti Sasanid pada pertengahan abad ke tiga Masehi dan di sanalah raja Anusyirwan (531-579) mendirikan lembaga studi filsafat dan kedokteran di mana guru-guru besarnya mayoritas terdiri dari orang yang beragama Kristen Nestorian. Lembaga ini telah mengeluarkan banyak ulama dan ahli filsafat, dokter-dokter seperti Ali Bachtisyu' dan lain-lain. Lembaga ini dipandang sebagai satu-satunya yang terbesar dalam abad pertengahan. Kota ini ditaklukkan oleh Utbaah bin Ghazwan pada masa Khalifah Umar bin al-Khattab. Ali al-Jumbulaty dan Abdul Futuh al-Tuwanisy, Perbadingan Pendidikan Islam, terj. Oleh H.M. Arifin, judul aslinya, Dirasat al-Muqaranat fi Tarbiyyah al-Islamiyyah, ( Jakarta: Rineka Cipta, 2002), h. 71.
} 
masjid-masjid atau madrasah. ${ }^{39}$ Perkembangan pesat lembaga pendidikan tinggi Islam, terjadi sebelum tumbuhnya kehidupan ilmiah di Paris dan Bologna di Barat Kristen. Universitas-universitas seperti yang dikenal sekarang baru tumbuh setelah abad ke-12 di Italia dan Prancis, lalu kemudian ke negara-negara lainnya di Eropa.

Menurut Azyumardi Azra, madrasah pada periode sebelum Nizamiyah sudah ada yang muncul, seperti penelitian Richard Bulliet yang berhasil mengungkap eksistensi madrasah-madrasah tertua yang ada di kawasan Nisahpur di Iran. Pada sekitar tahun 400H/1009 M terdapat madrasah al-Bayhaqiyah yang didirikan oleh Abu Hasan al-Bayhaqy (w.414/1023M). Bulliet bahkan menyebutkan terdapat 39 madrasah di wilayah Persia, yang berkembang dua abad sebelum madrasah Nizamiyah, yang tertua adalah madrasah "Miyan Dahiya" yang didirikan oleh Abu Ishaq Ibrahim ibn Mahmud di Nisahpur. Pendapat ini didukung oleh sejarahwan Muslim Naji Ma'ruf yang menyatakan bahwa di Khurasan telah berkembang madrasah sekitar 165 tahun sebelum kemunculan Nizamiyah, juga pada masa pemerintahan Sultan Mahmud al-Ghaznawi (388-421/998-1030M), juga terdapat madrasah Sa'idiyah. ${ }^{40}$ Terlapas dari kontroversi kesejarahan institusi pendidikan Islam, secara faktual lembaga-lembaga pendidikan tersebut baik madrasah maupun alJami'ah merupakan pusat diseminasi integrasi intelektual yang melahirkan konsep integrasi ilmu dalam Islam. Kepaduan konsep tentang integrasi keilmuan itu tercermin dari semangat pengembangan dunia akademik yang telah terbangun dengan kuat dan kemuadian diadopsi oleh dunia Barat dan diwariskan pada era renaisance yang sangat berpengauh pada perkembangan disiplin ilmu hingga sekarang.

\section{PENUTUP}

Isu tentang integrasi ilmu dalam Islam, menjadi sangat sentral peranannya ketika dihubungkan dengan sejarah dinamika pendidikan Islam terutama perkembangan institusi pendidikan Islam yang telah dibangun sejak kemunculam Islam sebagai agama yang sangat berpengaruh bagi kemajuan peradaban umat manusia. Secara faktual lembaga-lembaga pendidikan Islam menjadi basis pengkajian berbagai disiplin ilmu sekaligus tempat bertemunya para ulama Islam yang konsens terhadap tradisi intelektual Islam yang sangat kaya.

Upaya integrasi ilmu dalam Islam, sudah menjadi tugas mulia para ilmuan ditengah pengaruh sekularisme Barat yang mendominasi paradigma keilmuan modern. Salah satu usaha itu antara lain dengan melihat aspek sejarah pengembangan ilmu dalam Islam, dan mencermati peran institusi pendidikan sebagai tempat persemaian berbagai ilmu dalam Islam supaya tetap terlihat warisan Islam sekaligus identitas kultural keilmuan Islam dalam kerangka modernitas, sehingga ilmu yang berkembang tidak tercerabut dari akar fundamental Islam, dengan keagungan warisan intelektualisme dan peradabannya.

\footnotetext{
${ }^{39}$ Mehdi Nakosteen, History of Islamic Origins of Western Education, (Boulder: University of Colorado Press, 1964), h. 34-35. Lihat juga Charles Michael Stanton, Pendidikan Tinggi, h. 51.

${ }^{40}$ Azyumardi Azra, "Pendidikan Tinggi Islam dan Kemajuan Sains (Sebuah Pengantar)", dalam Charles Michael Stanton, Pendidikan Tinggi dalam Islam, h.vi.
} 


\section{DAFTAR PUSTAKA}

Abuddin Nata, Konsep Pendidikan Ibnu Sina, Disertasi pada Program Pascasarjana IAIN Syarif Hidayatullah Jakarta, 1997 Jakarta: IAIN, 1997.

Ahmad Syalaby, History of Muslim Education, (Beirut: Dar al-Kasshaf, 1954)

A.S. Triniton, Muslim Education in the Midle Ages, (London: Luzac, 1957)

Ali al-Jumbulaty dan Abdul Futuh al-Tuwanisy, Perbadingan Pendidikan Islam, terj. Oleh H.M. Arifin, judul aslinya, Dirasat al-Muqaranat fi Tarbiyyah al-Islamiyyah, ( Jakarta: Rineka Cipta, 2002)

Azyumardi Azra, "Pendidikan Tinggi Islam dan Kemajuan Sains (Sebuah Pengantar)", dalam Charles Michael Stanton, Pendidikan Tinggi dalam Islam, terjemahan dari Higher Learning in Islam, penerjemah H.Affandi dan Hasan Asari, (Jakarta: Logos, 1994)

Charles Michael Stanton, Pendidikan Tinggi Dalam Islam, terjemahan dari Higher Learning in Islam, penerjemah H.Affandi dan Hasan Asari, (Jakarta: Logos, 1994)

Cemil Akdogan, Asal-Usul Sains Modern dan Kontribusi Islam, dalam Majalah Pemikiran dan Peradaban Islam, Islamia, Th 1 No 4, Januari-Maret 2005, (Jakarta: Islamia, 2005)

George Makdisi, The Rise of Colleges, (Edinburgh: Edinburgh University Press, 1981) , "On The Origin and development of The Colleges in Islam and The West", dalam Khalil E Semaan (ed.), Islam and Medieval West, (Al-Bany: Suny Press, 1980)

H.S. Nasr, "Mulla Shadra: His Teaching" dalam Nasr dan Oliver Leaman, History of Islamic Philosophy, Jilid I, (London:Routledge, 1996)

Ibnu Taymiyyah dalam buku Minhaj al-Sunnah dan Al-Radd 'ala al-Mantiqiyyin (Mesir: n.d) Ibnu Sina, dalam kitab Al-Hidayah, (Kairo: n.d).

Juhaya S Praja, Filsafat dan Metodologi Ilmu Dalam Islam, (Bandung: Teraju, 2002),

Mehdi Golshani, Melacak Jejak. Tuhan Dalam Sains Tafsir Islami atas Sains, terjemahan judul aslinya, Issues in Islam and Science, Cet. I, (Bandung: Mizan, 2004).

Mehdi Nakosteen, History of Islamic Origins of Western Education, (Boulder: University of Colorado Press, 1964)

Mulyadhi Kartanegara, Menembus Batas Waktu, Panorama Filsafat Islam, (Bandung: Mizan, 2002)

Muzayyin Arifin, Filsafat Pendidikan Islam, (Jakarta: Bumi Aksara, 2003)

Osman Bakar, Hierarki Ilmu: Membangun Rangka Pikir Islamisasi Ilmu, (Bandung: Mizan, 1997)

Sayyid Quthb, Fi Zhilal al-Qur'an, (Beirut: Dar Ihya’ al-Turats al-‘Araby, 1386H) 
